\title{
"EDML1": a chronology for the EPICA deep ice core from Dronning Maud Land, Antarctica, over the last 150000 years
}

\author{
U. Ruth ${ }^{1}$, J.-M. Barnola ${ }^{2}$, J. Beer ${ }^{3}$, M. Bigler ${ }^{4,7}$, T. Blunier ${ }^{4}$, E. Castellano ${ }^{5}$, H. Fischer ${ }^{1}$, F. Fundel ${ }^{1}$, P. Huybrechts ${ }^{1,8}$, \\ P. Kaufmann ${ }^{4}$, S. Kipfstuhl ${ }^{1}$, A. Lambrecht ${ }^{1}$, A. Morganti ${ }^{5}$, H. Oerter ${ }^{1}$, F. Parrenin ${ }^{2}$, O. Rybak ${ }^{1}$, M. Severi ${ }^{5}$, \\ R. Udisti ${ }^{5}$, F. Wilhelms ${ }^{1}$, and E. Wolff ${ }^{6}$ \\ ${ }^{1}$ Alfred-Wegener-Institute for Polar and Marine Research, Bremerhaven, Germany \\ ${ }^{2}$ Laboratoire de Glaciologie et Géophysique de l'Environnement, CNRS, Grenoble, France \\ ${ }^{3}$ Swiss Federal Institute of Aquatic Science and Technology, EAWAG, Dübendorf, Switzerland \\ ${ }^{4}$ Climate and Environmental Physics, Physics Institute, University of Bern, Bern, Switzerland \\ ${ }^{5}$ Department of Chemistry, University of Florence, Florence, Italy \\ ${ }^{6}$ British Antarctic Survey, Cambridge, UK \\ ${ }^{7}$ Ice and Climate Research, Niels Bohr Institute, University of Copenhagen, Denmark \\ ${ }^{8}$ Departement Geografie, Vrije Universiteit Brussel, Brussels, Belgium
}

Received: 14 February 2007 - Published in Clim. Past Discuss.: 12 March 2007

Revised: 15 June 2007 - Accepted: 30 July 2007 - Published: 7 August 2007

\begin{abstract}
A chronology called EDML1 has been developed for the EPICA ice core from Dronning Maud Land (EDML). EDML1 is closely interlinked with EDC3, the new chronology for the EPICA ice core from Dome-C (EDC) through a stratigraphic match between EDML and EDC that consists of 322 volcanic match points over the last $128 \mathrm{ka}$. The EDC3 chronology comprises a glaciological model at EDC, which is constrained and later selectively tuned using primary dating information from EDC as well as from EDML, the latter being transferred using the tight stratigraphic link between the two cores. Finally, EDML1 was built by exporting EDC3 to EDML. For ages younger than $41 \mathrm{ka}$ BP the new synchronized time scale EDML1/EDC3 is based on dated volcanic events and on a match to the Greenlandic ice core chronology GICC05 via ${ }^{10} \mathrm{Be}$ and methane. The internal consistency between EDML1 and EDC3 is estimated to be typically $\sim 6$ years and always less than 450 years over the last $128 \mathrm{ka}$ (always less than 130 years over the last $60 \mathrm{ka}$ ), which reflects an unprecedented synchrony of time scales. EDML1 ends at $150 \mathrm{ka}$ BP ( $2417 \mathrm{~m}$ depth) because the match between EDML and EDC becomes ambiguous further down. This hints at a complex ice flow history for the deepest $350 \mathrm{~m}$ of the EDML ice core.
\end{abstract}

Correspondence to: U. Ruth

(uruth@awi-bremerhaven.de)

\section{Introduction}

The chronology of an environmental archive is among the most fundamental aspects in paleo-climatology because it is an important basis for most data interpretation, particularly with respect to phasing between events at different sites (EPICA-community-members, 2006) and to cyclicity (Ditlevsen et al., 2007; Rahmstorf, 2003). Techniques for the development of an ice-core chronology (or time scale) comprise (i) counting of annual layers if they are preserved in the core and the analytical resolution is sufficient, (ii) ageadoption of independently dated and unambiguously identified reference horizons such as selected volcanic eruptions, magnetic anomalies, as well as transitions or anomalies of temperature, aerosol tracers, gas composition, or other parameters, (iii) glaciological ice-flow modelling at various complexity and (iv) tuning of climatic and "non-climatic" parameters to orbital insolation changes, (e.g. Hammer et al., 1978; Parrenin et al., 2007; Schwander et al., 2001). While the chronologies should be as "correct" as possible in an absolute sense, a lot more can be learned from climatic records if they are compared to others on the basis of a synchronised time scale. Even if such a time scale is uncertain in an absolute sense, important questions regarding leads, lags and synchronicity of climatic events in two or more archives can be investigated only if their time scales are sufficiently synchronised. Therefore, for the two ice cores within the European Project for Ice Coring in Antarctica (EPICA), for the core (EDC) from Dome C, reaching

Published by Copernicus Publications on behalf of the European Geosciences Union. 
far back in time (EPICA-community-members, 2004), and for the higher-resolution core (EDML) from Dronning Maud Land (EPICA-community-members, 2006), a new synchronised time scale called EDML1/EDC3 was constructed, which considered dating inputs from both cores. This was possible due to a tight stratigraphic link between the two cores. The scope of this paper is to summarize the EDMLaspects of this dating procedure. For further details on strategy and methods of the EDML1/EDC3 time scale see Parrenin et al. (2007) and other papers in this special issue.

The EDML ice core was drilled at Kohnen station $\left(75^{\circ} 00^{\prime} \mathrm{S}, 0^{\circ} 04^{\prime} \mathrm{E}, 2892 \mathrm{~m}\right.$ (WGS84)) in the interior of Dronning Maud Land (DML), East Antarctica. The current snow accumulation rate is $64 \mathrm{~kg} / \mathrm{m}^{2}$ per year (Oerter et al., 2004), which makes it a potential site for layer counting during the Holocene. Although stochastic counting errors may be limited to a tolerable amount, an unconstrained counting leads to the danger of accumulating systematic errors. For the Holocene section it therefore seems preferable to transfer the well-established, counted Greenlandic ice core chronologies by matching profiles of Antarctic ${ }^{10} \mathrm{Be}$ production rates to the one from GRIP and to adopt the new unified Greenlandic Ice Core Chronology GICC05 (Rasmussen et al., 2006; Vinther et al., 2006). However, layer counting should still be attempted at EDML to interpolate between adopted control points.

The EDML drill site is located on a very gentle slope ( 0.7 per mill), $30 \mathrm{~km}$ west of the point where the main ice divide in DML coming from the east branches off into two ice divides running approximately to the northwest and southwest. The horizontal flow velocity at the drill site is $0.76 \mathrm{~m} / \mathrm{a}$ (Wesche et al., 2007). Thus, buried layers of ice originated at a surface position upstream of the drill site at higher elevation. Therefore, unlike for dome-positions such as EDC or GRIP, a 1-D glaciological ice flow model cannot be employed to find a realistic chronology. Instead, a 3-D glaciological model is necessary to consider the full ice flow dynamics and to take into account upstream variations of the snow accumulation rate (Huybrechts et al., 2007 ${ }^{1}$ ). For example, the ice in the EDML ice core with an age of $150 \mathrm{ka}$ originated $160 \mathrm{~km}$ upstream, where at present the surface is $240 \mathrm{~m}$ higher than at EDML and based on model calculations the accumulation is expected to be reduced by $35 \%$ compared to the drill site. Furthermore, accumulation does not only show a decreasing trend with increasing surface elevation (Oerter et al., 2000) but also shows considerable accumulation anomalies in excess of $20 \%$ on the scale of several $10 \mathrm{~km}$ (Eisen et al., 2005; Rotschky et al., 2004). If caused by underlying bedrock topography such variations would not be

\footnotetext{
${ }^{1}$ Huybrechts, P., Rybak, O., Pattyn, F., Ruth, U., and Steinhage, D.: Ice thinning, upstream advection, and non-climatic biases for the upper $89 \%$ of the EDML ice core from a nested model of the Antarctic ice sheet, Clim. Past Discuss., 3, 693-727, 2007, http://www.clim-past-discuss.net/3/693/2007/.
}

random but stationary in space and must be prescribed in the model because in the ice core they would appear as variations over time. The resulting complexity of the 3-D glaciological model is such that an inverse parameterization method, used in 1-D models to make the modeled time scale fit prescribed control windows (Parrenin et al., 2007), becomes impractical.

Thus, the strategy chosen for dating the EDML ice core was to construct first a tight stratigraphic link between the EDML and EDC ice cores mainly based on a volcanic synchronization (see also Severi et al., 2007). Using this stratigraphic link, selected dating constraints from EDML were transferred to EDC and were considered in the construction of the new modeled time scale for EDC, called EDC3 (Parrenin et al., 2007). Finally, the dependent timescale called EDML1 was established by transferring EDC3 from EDC to EDML using the same stratigraphic EDML-EDC link. All EDML1/EDC3 dates are given as years before present (a BP) with reference to AD 1950.

\section{EDML-EDC stratigraphic link}

The stratigraphic link between the EDML and EDC ice cores was established by matching volcanic events in the cores down to $2366.1 \mathrm{~m}$ in EDML, which corresponds to $1683.93 \mathrm{~m}$ in EDC99 or an EDML1/EDC3-date of $128.3 \mathrm{ka}$ BP. Beyond $2366.1 \mathrm{~m}$ the stratigraphic link of EDML to EDC was established using profiles of dust concentration and stable water isotopes (see below). A complete list of all stratigraphic match points used is given in Table S1 (see the electronic supplement http://www.clim-past.net/3/475/2007/ cp-3-475-2007-supplement.zip).

It should be noted that there are two EPICA cores at Dome C: the $\sim 788 \mathrm{~m}$ deep core $(\sim 45 \mathrm{ka} \mathrm{BP})$ called EDC96 (drilling commenced in 1996) with its time scale originally being EDC1 (Schwander et al., 2001) and the core to bedrock called EDC99 with its timescale originally being EDC1 back to $45 \mathrm{ka} \mathrm{BP}$ and EDC2 beyond (EPICA-communitymembers, 2004). The last volcanic match of EDML to core EDC96 is (EDML depth $1435.08 \mathrm{~m} / \mathrm{EDC}$ depth $778.36 \mathrm{~m}$ ); the first match to core EDC99 is $(1439.06 \mathrm{~m} / 780.59 \mathrm{~m})$. At the transition from EDC96 to EDC99 there is a small depth off-set of $73 \mathrm{~cm}$ (Wolff et al., 2005).

Further, it should be noted that there are also two cores at Kohnen station: the $\sim 150 \mathrm{~m}$ deep core B32, which was drilled $1.7 \mathrm{~km}$ west (downstream) from the EDML drill site during the pre-site survey in the 1997/98 season and has a counted chronology (Traufetter et al., 2004), and the main core called EDML. For the top $113 \mathrm{~m}$ of EDML the counted chronology was transferred from B32 to the EDML deep core (matching based on DEP peaks in the 3-inch access drilling of the EDML core and $\mathrm{SO}_{4}$ peaks in B32). There is a considerable depth off-set between EDML and B32 of $>5 \mathrm{~m}$ at $150 \mathrm{~m}$ depth. The volcanic horizons used to translate be- 
Table 1. Parameters used to stratigraphically link EDML and EDC for different EDML depth ranges. Parameters are given as [EDML/EDC]pairs. DEP denotes "Dielectric Profiling" of the frozen ice. Cond. denotes the "electrolytical conductivity" after melting the ice. $\mathrm{DEP}, \mathrm{SO}_{4}$ (sulphate concentrations) and Cond. were used to identify corresponding spikes (i.e. singular events) caused by volcanic deposits. Insoluble dust concentrations and stable isotopes $\left(\delta^{18} \mathrm{O}, \delta \mathrm{D}\right)$ were used to identify corresponding features in the respective profiles.

\begin{tabular}{ccccc}
\hline $\begin{array}{l}\text { EDML } \\
\text { depth range } \quad \begin{array}{l}\text { Parameter } \\
\text { EDML/EDC }\end{array}\end{array}$ & DEP/DEP & $\mathrm{SO}_{4} / \mathrm{SO}_{4}$ & $\begin{array}{c}\mathrm{Cond} / \mathrm{SO}_{4} \\
\mathrm{Cond} / \mathrm{Cond}\end{array}$ & $\begin{array}{c}\text { Dust/Dust } \\
\delta^{18} \mathrm{O} / \delta \mathrm{D}\end{array}$ \\
$\downarrow$ & & & & \\
\hline $\begin{array}{c}0-113 \mathrm{~m} \\
(-0.05-1.2 \mathrm{ka} \mathrm{BP})\end{array}$ & $\times$ & & \\
$113-1050 \mathrm{~m}$ & $\times$ & $\times$ & \\
$(1.2-24 \mathrm{ka} \mathrm{BP})$ & $\times$ & $\times$ & $\times$ \\
$1050-1556 \mathrm{~m}$ & & & $\times$ \\
$(24-52 \mathrm{kaBP})$ & $\times$ & & \\
$1556-1901 \mathrm{~m}$ & & & \\
$(52-75 \mathrm{ka} \mathrm{BP})$ & & & \\
$1901-2366 \mathrm{~m}$ & & & \\
$(75-128 \mathrm{ka} \mathrm{BP})$ & & & \\
$>2366 \mathrm{~m}$ & & & \\
$(>128 \mathrm{ka} \mathrm{BP})$ & & & \\
\end{tabular}

tween EDML, B32 and EDC are listed in Table S2 (see the electronic supplement http://www.clim-past.net/3/475/2007/ cp-3-475-2007-supplement.zip).

\subsection{Volcanic match points}

Explosive volcanic eruptions inject large quantities of sulphuric acid $\left(\mathrm{H}_{2} \mathrm{SO}_{4}\right)$ and its gaseous precursor $\mathrm{SO}_{2}$ into the atmosphere, where $\mathrm{H}_{2} \mathrm{SO}_{4}$ /water droplets form. This leads to increased concentrations of $\mathrm{H}^{+}$and $\mathrm{SO}_{4}^{2-}$ in deposited snow. $\mathrm{H}^{+}$-anomalies can be identified in frozen ice by means of Dielectric Profiling (DEP) (Wolff et al., 1999) and the Electric Conductivity Method (ECM) (Clausen et al., 1997) or in melted samples by measuring the electrolytical conductivity (Cond) (Röthlisberger et al., 2000); $\mathrm{SO}_{4}^{2-}$-concentrations can be measured using Ion-Chromatography (IC) or Fast-IonChromatography (FIC) (Traversi et al., 2002). The deposits of large volcanic eruptions occur as singular events with durations of weeks to years and can be used as isochrones in ice cores. If found in two ice cores, a series of events resembling a pattern with characteristic intervals between the peaks or characteristic peak heights can be used to match the cores with high confidence. Slow but persistent diffusive broadening of $\mathrm{H}^{+}$and $\mathrm{SO}_{4}^{2-}$-peaks in the ice (Barnes et al., 2003) eventually limits the matching at greater depth.

During the volcanic synchronization between EDML and EDC, three groups of investigators first worked independently to generate a list of suggested matches, each group using different combinations of parameters (in the following denoted as [EDML/EDC]-pairs): (i) [DEP/DEP], (ii) $\left[\mathrm{SO}_{4}^{2-} / \mathrm{SO}_{4}^{2-}\right]$, and (iii) [electrolytical conductivity/$/ \mathrm{SO}_{4}^{2-}$ ]; the latter was double checked by [electrolytical conductivity/electrolytical conductivity], which however did not produce any different results. Table 1 gives an overview of the parameters involved for respective depth ranges. The profiles of insoluble dust concentrations were used for a first rough alignment of the two cores. This procedure is based on the assumption that the East Antarctic sites receive dust from a common Patagonian dust source during glacial times, and that changes in source strength, or in processes near the source, are the main control on the significant changes seen in both ice cores (Delmonte et al., 2006; Mulvaney et al., 2000). Each volcanic match was assigned a confidence value ranging from 1 meaning "certain" to 4 meaning "tentative". If a match consisted of a series of peaks with an unambiguous pattern clearly recognizable in both cores it was labelled "certain"; a match with no or only a weak pattern was labelled "tentative". The so-called "tentative" matches should be treated with more caution than the others but they do provide likely stratigraphic links. Although the choice of the confidence value is admittedly very subjective it still provides some indication of the reliability of each match.

After completion of the independent work of the three groups, the suggested matches were synoptically reviewed. There was great mutual support of the matches, and among the three groups only five matches proved incompatible with others and needed to be withdrawn. From the matches a "synthesis list" was generated to avoid double assignments and disturbances resulting from small off-sets of the depth scales associated with the different parameters used. This resulted in a list of 322 volcanic EDML-EDC matches (including 51 "tentative" matches). One of these matches was 


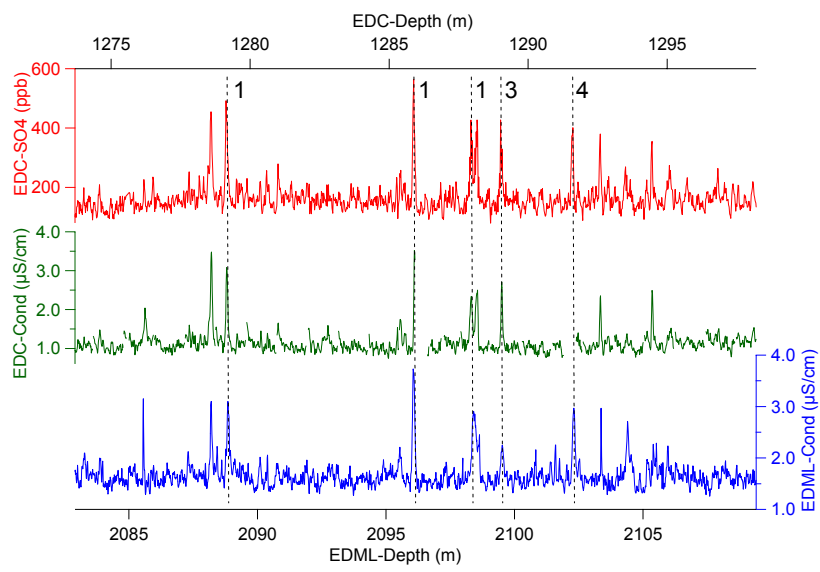

Fig. 1. Illustration of a volcanic match based on electrolytical conductivity (Cond) for EDML and $\mathrm{SO}_{4}$ concentrations or Cond for EDC. The section shown is from a depth range where peak diffusion is already noticeable at EDML. The matches are indicated as vertical dashed lines. Numbers given at each match refer to the confidence value attributed to the matches ranging from " 1 " ("certain") to "4" ("tentative"). The section shown covers the time from $\sim 90.1$ to $\sim 92.6 \mathrm{ka} \mathrm{BP}$.

independently confirmed by geochemical fingerprinting of associated tephra shards in both cores (M. Kohno, personal communication).

The volcanic matching was based on $\mathrm{SO}_{4}^{2-}$ concentration data where available, as this is a specific volcanogenic tracer for interior East-Antarctic sites (Udisti et al., 2004). For details and implications of the volcano-stratigraphic link see Severi et al. (2007). For ages older than $52 \mathrm{ka}$ there is no $\mathrm{SO}_{4}^{2-}$ data available yet and the matching was based on slightly less specific conductivity data, which however also provide good indication for volcanic events. Figure 1 illustrates examples of volcanic matches based on electrolytical conductivity from $\sim 2100 \mathrm{~m}$ EDML-depth $(\sim 92 \mathrm{ka} \mathrm{BP})$.

The volcanic matching becomes increasingly difficult below $1900 \mathrm{~m}$ (75 ka BP) being limited by considerable peak diffusion at EDML. Only the largest volcanic events can be identified, which is reflected by increasing intervals between adjacent match points. The last "certain" match is at $2273 \mathrm{~m}$ (115 ka BP). Beyond $2366 \mathrm{~m}$ (128 ka BP) there are no appreciable acidic spikes left in EDML because the volcanic acid deposits are too diffused to be clearly recognised.

\subsection{Non-volcanic match points}

A volcanic match is not feasible below $2366 \mathrm{~m}$ (128 ka BP) because of peak diffusion in the EDML core. It offered no solution to let the glaciological flow-model run freely beyond the last volcanic match as this produced ages too young for the termination of MIS6. This indicates that the annual layers at this depth are thinned more than expected. Below $2366 \mathrm{~m}$ EDML and EDC were thus linked via three match points based on insoluble dust concentrations and isotopes (EDML-depth/EDC99-depth/EDC3age): $(2382 \mathrm{~m} / 1745 \mathrm{~m} / 133 \mathrm{ka}),(2410 \mathrm{~m} / 1831 \mathrm{~m} / 148 \mathrm{ka})$, and $(2452 \mathrm{~m} / 1901 \mathrm{~m} / 162 \mathrm{ka})$. Given the extremely high covariance of $\delta^{18} \mathrm{O}$ and dust at EDC and EDML in the top part, it appears justified to assume a continuing synchroneity of these parameters also for deeper ice in the EDML and EDC ice core. The match at $2382 \mathrm{~m}$ is placed at mid-transition of termination 2 and has an estimated error of several centuries; the match at $2410 \mathrm{~m}$ is placed on an increase of dust concentrations and the match at $2452 \mathrm{~m}$ on a feature in dust and isotopes. The last two matches are increasingly uncertain, possibly by several thousand years (see supplemental Fig. S1 at http://www.clim-past.net/3/475/2007/ cp-3-475-2007-supplement.zip). The EDML1 chronology is restricted to $150 \mathrm{ka} \mathrm{BP}$ ( $2417 \mathrm{~m}$ depth) because the match becomes ambiguous beyond this level.

\subsection{Interpolation between the stratigraphic match points}

Between the match points a piecewise cubic Hermite interpolation (similar to cubic spline interpolation except that it produces no over-shoots) (MathWorks, 2002) was chosen to interpolate between EDML-depth and EDC-depth. Thus every EDML-depth $d_{\text {EDML }}$ between the match points was assigned a corresponding EDC-depth $d_{\mathrm{EDC}}$. Then the EDC3-age was determined for $d_{\mathrm{EDC}}$. That way the EDCaccumulation history (inferred from EDC isotopes during construction of EDC3) is used implicitly for interpolation between the match-points at EDML.

\section{Constructing the chronology}

The EDML1 time scale is based on EDC3, which is a modelled glaciological time scale at EDC, modified in places by tuning. EDC3 gives consistent ages, paleosnow-accumulation rates and ice thinning at EDC. Paleoaccumulation rates were reconstructed from isotopic temperatures at EDC, and model parameters were optimized such that the resulting time scale is consistent with the prescribed dating constraints. The resultant modelled scale was then tuned to force it through a set of particularly well-controlled points. Most dating constraints for the Holocene and late glacial period were "imported" from EDML, while others derive from direct comparisons from EDC to other palaeoclimatic records. In the following we summarize the dating constraints relevant for EDML1. For a detailed description see Parrenin et al. (2007).

\subsection{Dating constraints for EDML1/EDC3}

The primary dating constraints from EDML are dated volcanic eruptions during the last $\sim 1000$ years, a synchronization to the Greenlandic GICC 05 chronology via ${ }^{10} \mathrm{Be}$ (during Holocene) and methane (Termination 1). 
Table 2. Volcanic horizons used for constraining the EDML1/EDC3 time scale. EDML-depth is from the DEP data set of the 3-inch-access drilling. B32-depth and year are adopted from Traufetter et al. (2004), with the exception of the date used for Kuwae, which is a weighted average of AD $1454 \pm 5$ from B32 (Traufetter et al., 2004) and AD1459.5 from Law Dome (Palmer et al., 2001).

\begin{tabular}{lccc}
\hline Volcano & $\begin{array}{c}\text { EDML-Depth } \\
(\mathrm{m})\end{array}$ & $\begin{array}{c}\text { B32-Depth } \\
(\mathrm{m})\end{array}$ & $\begin{array}{c}\text { Year } \\
(\mathrm{AD})\end{array}$ \\
\hline Krakatau & 17.19 & 16.29 & $1884 \pm 0$ \\
Tambora & 24.94 & 23.8 & $1816 \pm 0$ \\
Huaynaputina & 46.10 & 44.35 & $1601 \pm 0$ \\
Kuwae & 59.11 & 56.8 & $1458 \pm 2$ \\
unknown/ & 75.38 & 72.57 & $1259 \pm 5$ \\
El Chichon? & & & \\
unidentified & 77.67 & 74.72 & $1228 \pm 6$ \\
unknown & 82.32 & 79.23 & $1171 \pm 6$ \\
\hline
\end{tabular}

The top part of the EDML1/EDC3 chronology is based on the counted time scale of B32. The counting was performed on high-resolution data of continuous flow analyses (CFA) and discrete ion chromatography (IC) of major ion composition (Sommer et al., 2000; Traufetter et al., 2004). Seven volcanic events, the oldest one of which dated to $779 \pm 5$ years BP, were selected to transfer the B32-dating to EDML1/EDC3 (see Table 2).

${ }^{10} \mathrm{Be}$ is a cosmogenic radionuclide like ${ }^{14} \mathrm{C}$; the production rate is modulated by solar activity and by the strength of the Earth's magnetic field and therefore include a variability that can be recognised globally. Changes in the production rate of ${ }^{10} \mathrm{Be}$ and ${ }^{14} \mathrm{C}$ provide a global signal which can be used to synchronize ice cores between the hemispheres or with the INTCAL tree ring chronology (Beer et al., 2002). Thus for Holocene, the EDML ${ }^{10} \mathrm{Be}$ record was matched to GICC05 via GRIP ${ }^{10} \mathrm{Be}$ and to INTCAL (see Fig. 2). An automated algorithm was used to shift and stretch the EDML ${ }^{10} \mathrm{Be}$ production rates until the correlation to the GRIP ${ }^{10} \mathrm{Be}$ production rates (on the GICC05 chronology) is maximized. This resulted in a proposed GICC05-like chronology for EDML. A similar dating exercise had been performed for the Vostok BH1 core (G. M. Raisbeck, personal communication, 1998); and these two dating approaches were checked for consistency via a sequence of volcano-stratigraphic links from EDML to BH1 (via EDC) (J.-R. Petit, personal communication, 2006; Severi et al., 2007; Udisti et al., 2004; Wolff et al., 1999). Finally, two control points were placed to constrain the EDML1/EDC3 chronology at $2.75 \mathrm{ka} \mathrm{BP}$ and $5.3 \mathrm{ka}$ BP, where EDML and Vostok BH1 agreed to within a few decades. Both control points were chosen during times of considerable variations of the ${ }^{10} \mathrm{Be}$ production rate, thus adding further confidence on the matching approach. GICC05-dates were applied for the two control points cho-

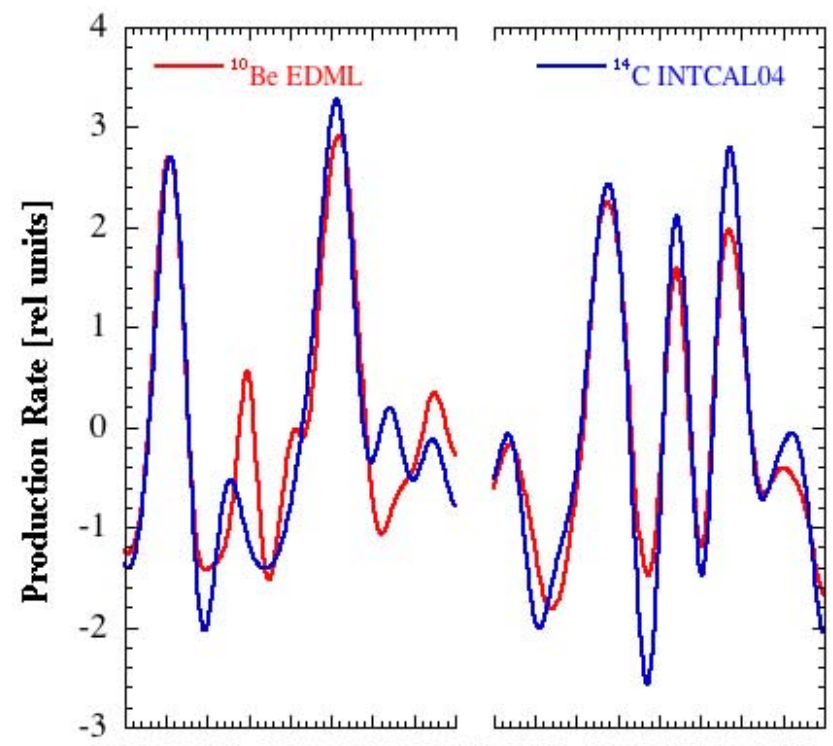

220024002600280030005100530055005700

\section{Age [cal years BP]}

Fig. 2. Comparison of ${ }^{10} \mathrm{Be}$ concentrations from EDML (red line) with the ${ }^{14} \mathrm{C}$ production rate derived from INTCAL04 (blue line) using a carbon cycle model. The data is shown after age-adjustment of the EDML data to maximize cross-correlation. Before matching the data, they were spline interpolated to 2 years and then band-pass filtered (100-1000 years). An analogous exercise was undertaken to match ${ }^{10} \mathrm{Be}$ concentrations from EDML to ${ }^{10} \mathrm{Be}$ concentrations from GRIP using the GICC05 time-scale. Two control points were selected at $2.75 \mathrm{ka} \mathrm{BP}$ and $5.3 \mathrm{ka}$ BP to constrain EDML1/EDC3.

sen, but within the error bar of 50 years used at this depth when building EDC3 (Parrenin et al., 2007) there is no difference between the Greenlandic GICC05 ice core chronology and the INTCAL tree ring chronology.

Synchronisation of Antarctic and Greenlandic ice core records is also possible via methane concentrations, which have a common global signature and show rapid jumps that closely follow jumps in Greenland temperature. However, the low accumulation rate at EDC leads to a large uncertainty for the calculation of delta-depth (the depth difference between ice and enclosed air of the same age) and deltaage (the age difference between ice and enclosed air at the same depth). For EDML this uncertainty is strongly reduced due to a higher accumulation rate and a higher annual mean temperature (e.g. for the Younger Dryas-Preboreal transition $\Delta \mathrm{age}_{\mathrm{EDC}} \approx 3200 \pm 770 \mathrm{yrs}$ while $\Delta \mathrm{age}_{\mathrm{EDML}} \approx 1000 \pm 200 \mathrm{yrs}$ ) (Blunier et al., 2007). For the rapid warmings at the onset of the Bölling and the demise of the Younger Dryas the EDML methane data were matched to the Greenlandic NGRIP stable isotope record (NGRIP-project-members, 2004). The corresponding NGRIP-GICC05 dates were transferred first from the EDML gas depth-scale to the EDML ice depth-scale by subtracting the calculated delta-depth and then further on 


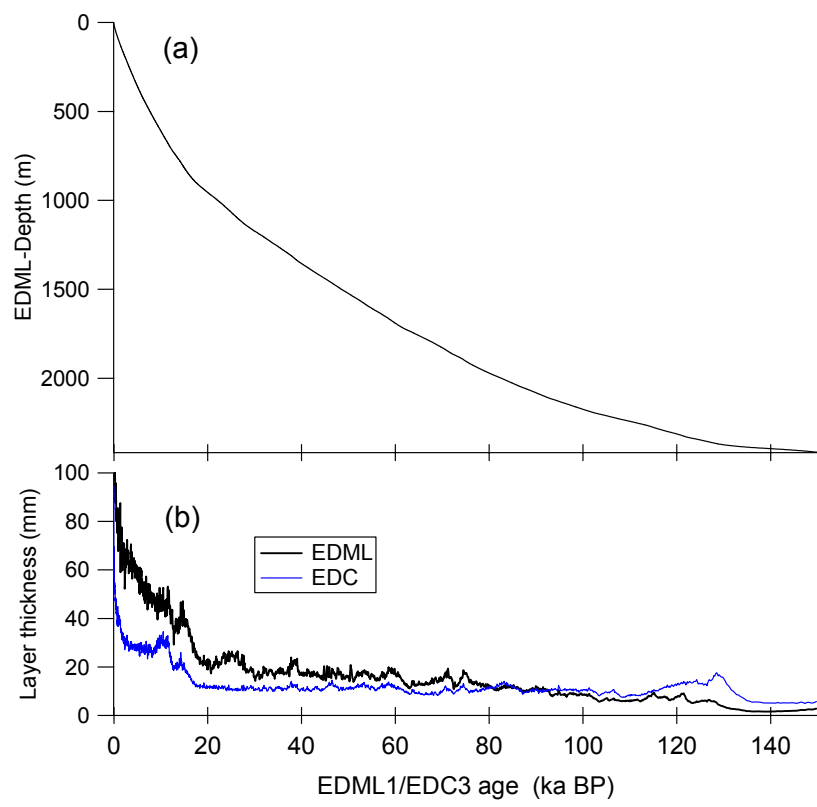

Fig. 3. Depth-age relationship for the EDML ice core (a), and corresponding thickness of annual layers (b) shown as true depth (not corrected for firn compression) for EDML (black, bold line) and for EDC (blue, fine line). Note, that variations in the EDML layer thickness may also include possible spatial upstream variations in snow accumulation in the past while upstream effects at the dome position of EDC do not exist.

from EDML to EDC via the volcanic match between the two cores (Severi et al., 2007).

Apart from these constraints from EDML, the EDC3 chronology was further constrained based on dating information from EDC at the ${ }^{10} \mathrm{Be}$-peak of the Laschamp event and during Termination 2. For Laschamp, the ${ }^{10} \mathrm{Be}$ doublepeak centered at $740.08 \mathrm{~m}$ in EDC96 (Raisbeck et al., 2007) was placed at $41.2 \mathrm{ka} \mathrm{BP}$ following the layer-counted Greenlandic GICC05 date (Andersen et al., 2006; Svensson et al., 2006). After completion of the EDML1 time scale Laschamp was also measured and identified in EDML and confirmed the volcanic synchronization. During Termination 2 a rapid methane event is used to place $1698.91 \mathrm{~m}$ EDC99 (ice), which corresponds to $2370.5 \mathrm{~m}$ in EDML, at $129.2 \mathrm{ka} \mathrm{BP}$ on the basis of U/Th speleothem dates. For more details on the construction of EDC3 and a list of all control points used for EDC3, including those beyond the range of the synchronisation with EDML, see Parrenin et al. (2007).

\subsection{Time scale results and dating uncertainties}

The resulting depth-age relation for EDML is shown in Fig. 3 and provided numerically in Table S3 (see online supplement http://www.clim-past.net/3/475/2007/ cp-3-475-2007-supplement.zip). The associated annual layer thickness $\lambda$ is also shown: During the densification process $\lambda$ decreases rapidly from $>150 \mathrm{~mm}$ at the surface to $\sim 70 \mathrm{~mm}$ at $100 \mathrm{~m}$ depth $(\sim 1 \mathrm{ka} \mathrm{BP}) ; \lambda$ is $>45 \mathrm{~mm}$ for the entire Holocene. During MIS2-MIS4 $\lambda$ is around $20 \mathrm{~mm}$ at EDML. $\lambda$ is always larger at EDML than at EDC for the last $\sim 80 \mathrm{ka}$; also, variations of $\lambda$ are more distinct at EDML, which may possibly be related to climatic variations of accumulation rates; between $80 \mathrm{ka} \mathrm{BP}$ and $93 \mathrm{ka} \mathrm{BP} \lambda$ is about the same for EDML and EDC $(\sim 10 \mathrm{~mm})$; and for ages older than $\sim 93 \mathrm{ka}$ BP $\lambda$ is larger at EDC than at EDML. Thus, the time-resolution of the data is better at EDML for the last $80 \mathrm{ka}$, if not longer considering that surface reworking or wind erosion may be more destructive at Dome $\mathrm{C}$ due to the lower accumulation rate.

The dating uncertainty for EDML1 is the sum of three possible contributions: (i) the uncertainty of the EDC3 time scale, (ii) possible errors in the stratigraphic match between EDML and EDC, and (iii) the uncertainty of the stratigraphic interpolation in between these match points.

The absolute dating uncertainty for EDC3 is estimated by Parrenin et al. (2007) to be $\sim 100$ a for most of the Holocene, and increases to $\sim 1.5 \mathrm{ka}$ at $40 \mathrm{ka} \mathrm{BP}$ and to $\sim 6 \mathrm{ka}$ at $130 \mathrm{ka}$ BP. A possible error in the EDML-EDC stratigraphic match is difficult to quantify, but probably minimal. Although theoretically still possible, the chance for volcanic match-point errors was minimized: Several teams worked independently, and dust records were used to avoid severe apparent mismatches between the cores. Further, the differentiated depth-depth relationship was checked to avoid severe anomalies of the depth-age relationship. The uncertainty of the stratigraphic interpolation between the match points is estimated in the next subsection; this estimate also takes into account possible errors of the so-called "tentative" matches (see below).

As stated earlier, the match-point error may be considerable for the non-volcanic match-points used below $2366 \mathrm{~m}$ (128 ka BP). Here, the synchronisation uncertainty amounts to several 100 years during termination 2 and quickly increases to several 1000 years at $150 \mathrm{ka}$ BP. The stratigraphic synchronisation error will in any case be less than the absolute time scale uncertainty of EDC3.

\subsection{Uncertainty of the stratigraphic interpolation}

The median time span between two consecutive volcanic matches is 230 years and the maximum is 3800 years (at $125 \mathrm{ka} \mathrm{BP})$. For the period younger than $75 \mathrm{ka} \mathrm{BP}$ the median time span is 190 years and the maximum is 1500 years (at $66 \mathrm{ka} \mathrm{BP}$ ). Figure $4 \mathrm{~b}$ shows a time series of these values and also differentiates between all matches and all "nontentative" matches.

An empirical relationship was derived to estimate the synchronization error between the volcanic match points. This was done by determining the age shift $\Delta t$ at the EDMLdepth $d_{i}$ of every volcanic match point that resulted from repeating the interpolation after removing this point from the 


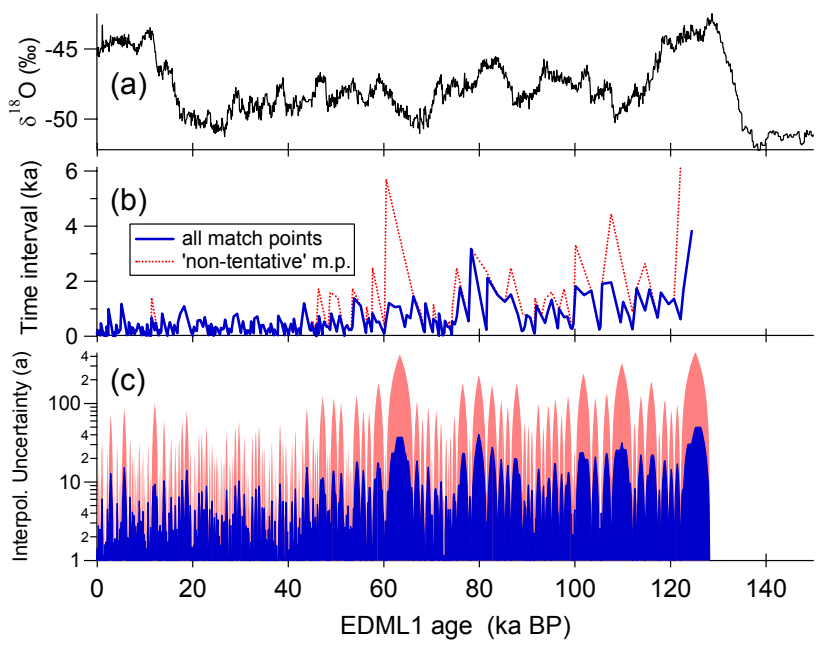

Fig. 4. (a): The EDML-temperature proxy $\delta^{18} \mathrm{O}$ (uncorrected for upstream effects) in 100-year averages (black) is shown for orientation (EPICA-community-members, 2006). (b): Illustration of time between consecutive volcanic EDML-EDC match points along the EDML core. The blue solid line results from considering all match points, the red dotted line results from considering only the socalled "non-tentative" match points. (c): Interpolation uncertainty for EDML, i.e. the empirically expected interpolation error between the volcanic EDML-EDC match points. The most-probable (blue) and the expected-maximal (light red) synchronisation error are shown. For details see text.

table of synchronization match-points. Subsequently, the adjacent match points were also removed and the interpolation repeated until the nearest remaining match point was more than 10000 years away. The resulting age shifts for each $d_{i}$ are interpreted as the potential synchronisation errors that would have resulted if the match points had not been chosen. Plotting each age shift $\Delta t$ vs. the age gap $t_{\text {nearest }}$ to the nearest (remaining) match point leads to an empirical estimate of the interpolation uncertainty depending on $t_{\text {nearest }}$. Figure 5 illustrates the distribution of the interpolation uncertainty. Apparently, the probable interpolation error increases linearly with the $t_{\text {nearest }}$.

From the data in Fig. 5 the most-probable interpolation error $<$ err $>$ and the expected-maximal interpolation error $<\operatorname{err}_{\max }>$ can be evaluated. This was done by calculating first the ratio $b=\Delta t / t_{\text {nearest }}$ for each data point, then grouping all data points into 22 bins $j$ of $t_{\text {nearest, }}$ and subsequently calculating the mean $b_{\text {mean, } j \text { and maximum }}$ $b_{\text {max }, j}$ slope for each of the 22 bins. Averaging over all bins $j$ yields $<\operatorname{err}>=$ mean $\left(b_{\text {mean }, j}\right)=(2.6 \pm 0.5$ years $/ 100$ years $) \cdot t_{\text {nearest }} \quad$ and $\quad<\operatorname{err}_{\max }>=\operatorname{mean}\left(b_{\max , j}\right)=(15 \pm 6$ years $/ 100$ years $) \cdot t_{\text {nearest }}$, i.e. if the nearest match point is 100 years away then the most-probable interpolation error is 2.6 years whereas the expected-maximal interpolation error is 15 years.

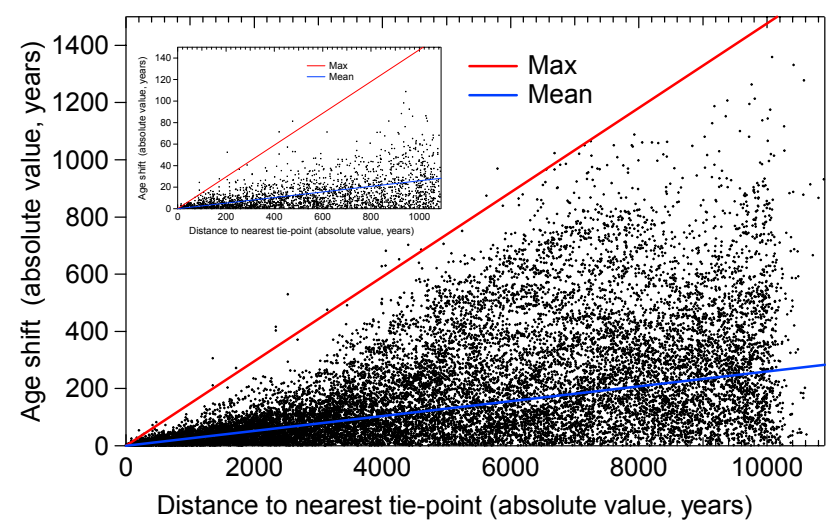

Fig. 5. Empirical estimate of the interpolation uncertainty between the match points. The age shift of every volcanic match point was calculated after it was no longer taken as a fixed match point; the resulting age shift is interpreted as the potential synchronisation error that would have resulted without the match point. The blue line indicates the most-probable interpolation error for any given distance to the nearest match point $(2.6 \pm 0.5$ years $/ 100$ years). The red line indicates the most expected-maximal interpolation error $(15 \pm 6$ years/100 years). See text for details.

The same results are obtained, regardless whether all volcanic match points are considered or only the "nontentative", or only Holocene or only Pleistocene match points. Most-probable and expected-maximal interpolation errors are indicated in Fig. 5 as blue and red lines. The value determined for $<\operatorname{err}_{\max }>$ is a conservative estimate, because $99.5 \%$ of all points deviate less than suggested by this estimate; this is not only true for large but also for small values of $d_{\text {nearest }}$ (see inset in Fig. 5). It proved important to use the interpolation method as described above, i.e. first transfer any given EDML-depth to its corresponding EDCdepth and secondly determine its age. As an alternative method it was tested to first determine the ages for all EDML match points and then directly interpolate depth to age (i.e. to not use implicitly EDC accumulation rates); this alternative method yielded interpolation uncertainties larger by $\sim 50 \%$ and therefore was not used.

The empirical parameterization for $<$ err $>$ and $<\operatorname{err}_{\max }>$ can be used to calculate the most-probable and expectedmaximal interpolation errors along the EDML ice core. The same parameter values are used for the full core, i.e. it is assumed that the nature of interpolation errors is the same throughout. For calculation of $<\operatorname{err}_{\max }>$ only the "nontentative" match points were considered and for $<$ err $>$ "tentative" match points were considered with $50 \%$ weight only, i.e. $<\operatorname{err}_{\max }>$ further increases around "tentative" match points and $<$ err $>$ is the average of considering all and only "non-tentative" match points. The resulting profiles are shown in Fig. 4c (data provided together with time scale in Table S3, see online supplement http://www.clim-past.net/ 3/475/2007/cp-3-475-2007-supplement.zip). For the past 


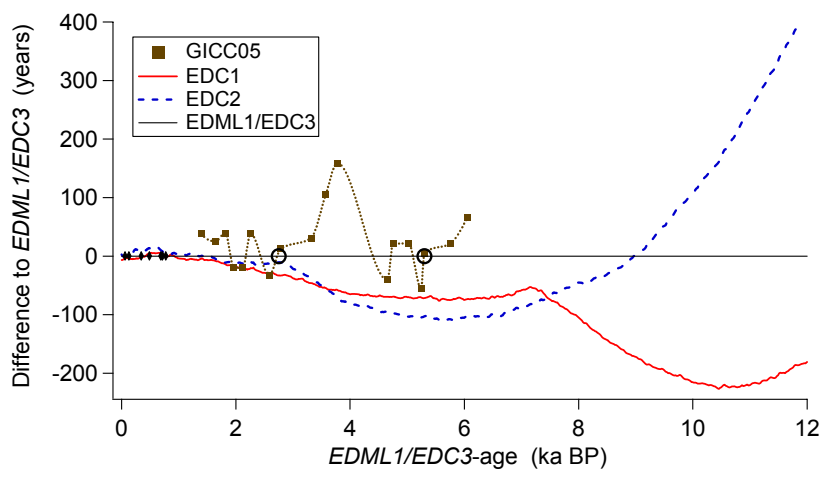

Fig. 6. Comparison of EDML1/EDC3 time scale with EDC1 (solid red line) and EDC2 (dashed blue line) time scales (both via the volcanic match EDML-EDC) and with the Greenlandic GICC05 (solid brown symbols and dotted line) time scale (via ${ }^{10} \mathrm{Be}-$ match EDML-GRIP). Positive numbers mean that the respective time scale gives an older date than EDML1/EDC3. Also marked are the volcanic control points (solid black symbols) and the two ${ }^{10} \mathrm{Be}$-based control points (open black circles) used during construction of the EDML1/EDC3 time scale.

$128 \mathrm{ka}$, the average values for $<\mathrm{err}>$ and $<\operatorname{err}_{\max }>$ are 6 and 42 years; the maximum values are 50 and 450 years, respectively. For the past $\sim 60 \mathrm{ka}<$ err $>$ is always less than 20 years and $<\operatorname{err}_{\max }>$ is always less than 130 years. Thus, the interpolation error is always small compared to the absolute dating uncertainty. This information will be important for discussing possible leads or lags between climatic signals in EDML and EDC.

\section{Comparison to other time scales for Holocene}

A comparison of the EDML1/EDC3 time scale to other time scales for the Pleistocene is given by Parrenin et al. (2007). Here we discuss the Holocene. Figure 6 shows the deviations of other ice core time scales from EDML1/EDC3. Given the close volcanic link between EDML and EDC it is straight-forward to evaluate deviations of the EDC1 and EDC2 chronologies. During the last 8000 years these timescales agree within 100 years - within even 20 years during the last 2000 years. During early Holocene and the last glacial termination the deviations increase to over 200 years reaching $\sim 500$ years $(\mathrm{EDC} 1)$ and $\sim 800$ years (EDC2) during the Late Glacial at around $20 \mathrm{ka}$ BP. We propose that the new EDML1/EDC3 chronology is a significant improvement for this period, however, it should be noted that EDC2 never was a recommended time scale for ages younger than $45 \mathrm{ka}$, because it was constructed using a single set of model parameters that were strongly influenced by constraints in the deeper part of the ice.

For the comparison of EDML1/EDC3 to the Greenlandic GICC05 time scale ${ }^{10} \mathrm{Be}$ production rates as inferred from EDML and GRIP were matched. Figure 6 shows the devi- ation of this GICC05-like chronology from EDML1/EDC3 from 1300 to 6000 years $\mathrm{BP}$, which is the period for which EDML- ${ }^{10} \mathrm{Be}$ data are available so far. The differences are typically less than 40 years, i.e. there is a considerable degree of interhemispheric consistency between the time scales EDML1/EDC3 and GICC05. The largest deviation is between 3300 and 4500 years BP, when the deviations increase to up to 160 years. However, this is a time where the ${ }^{10} \mathrm{Be}$ production rate shows only weak variations and the matching approach may possibly not be fully robust; therefore the EDML1/EDC3 chronology was not further constrained during this period.

\section{Conclusions}

A new ice core chronology has been developed jointly for the EPICA ice cores at Dronning Maud Land and Dome-C for the last $150 \mathrm{ka}$. Central to this new chronology is a detailed volcano-stratigraphic link between the two cores (Severi et al., 2007). Using this link all primary dating constraints from the EDML core were first transferred to EDC, where ice flow configurations are less complex. Inverse 1-D ice flow modelling at Dome- $\mathrm{C}$ was then used to interpolate between all dating constraints from EDML and EDC (Parrenin et al., 2007). The resulting time scale for EDC was finally transferred to EDML using the same volcano-stratigraphic link. This strategy combines several advantages: first, primary dating information was used from two cores together in one time scale; second, the complex ice flow configuration at EDML with upstream variations of accumulation rate and temperature do not compromise the chronology; and last but not least, unprecedented internal consistency is obtained between the two cores from different parts of Antarctica with relative dating uncertainties being always much less than the absolute dating uncertainties for the last $128 \mathrm{ka}$. This high degree of internal synchronization will be the important basis to investigate regional phase shifts (leads or lags) in highresolution data from the two EPICA ice cores.

Before $128 \mathrm{ka} \mathrm{BP}$ volcanic matching is impossible due to peak diffusion at EDML, and the match is based on dust and stable isotopes, which is still feasible back to $150 \mathrm{ka} \mathrm{BP}$ (2417 m depth), but gets increasingly uncertain. At EDML, layer thicknesses exhibit irregular thinnings below $\sim 2300 \mathrm{~m}$ depth. Reasons for this complexity may include large upstream effects, unknown variations in ice fabric and ice hardness, and the fact that the ice at bedrock is very close to the pressure-melting point. Results from numerical experiments with a 3-D model (Huybrechts et al., 2007¹) of the Antarctic ice sheet indicate that even slight variations of the geothermal heat flux $G$, which is not precisely constrained for DML (Fox-Maule et al., 2005; Shapiro and Ritzwoller, 2004), can potentially change the state of the ice at bedrock from freezing to melting at and upstream of the drill-site and therefore can strongly influence the chronology in the bottom $10 \%$ of 
the EDML ice core. Therefore, detailed modelling studies and further data analyses are necessary before building the chronology for the bottom $350 \mathrm{~m}$ of the EDML ice core.

Acknowledgements. This work is a contribution to the European Project for Ice Coring in Antarctica (EPICA), a joint European Science Foundation/European Commission scientific programme, funded by the EU and by national contributions from Belgium, Denmark, France, Germany, Italy, the Netherlands, Norway, Sweden, Switzerland and the United Kingdom. The main logistic support was provided by IPEV and PNRA (at Dome C) and AWI (at Dronning Maud Land). This is EPICA publication no. 174. Data are available from Pangaea (doi:10.1594/PANGAEA.602127).

Edited by: T. van Ommen

\section{References}

Andersen, K. K., Svensson, A., Rasmussen, S. O., Steffensen, J. P., Johnsen, S. J., Bigler, M., Röthlisberger, R., Ruth, U., SiggaardAndersen, M. L., Dahl-Jensen, D., Vinther, B. M., and Clausen, H. B.: The Greenland Ice Core Chronology 2005, 15-42 kyr. Part 1: Constructing the time scale, Quaternary Sci. Rev., 25, 32463257, doi:10.1016/j.quascirev.2006.08.002, 2006.

Barnes, P. R. F., Wolff, E., Mader, H. M., Udisti, R., Castellano, E., and Röthlisberger, R.: Evolution of chemical peak shapes in the Dome C, Antarctica, ice core, J. Geophys. Res., 108(D3), 4126, doi:10.1029/2002JD002538, 2003.

Beer, J., Muscheler, R., Wagner, G., Laj, C., Kissel, C., Kubik, P., and Synal, A.: Cosmogenic nuclides during Isotope Stages 2 and 3, Quaternary Sci. Rev., 21, 1129-1139, 2002.

Blunier, T., Spahni, R., Barnola, J.-M., Chappellaz, J., Loulergue, L., and Schwander, J.: Synchronization of ice core records via atmospheric gases, Clim. Past, 3, 325-330, 2007, http://www.clim-past.net/3/325/2007/.

Clausen, H. B., Hammer, C. U., Hvidberg, C. S., Dahl-Jensen, D., Steffensen, J. P., Kipfstuhl, J., and Legrand, M.: A comparison of the volcanic records over the past 4000 years from the Greenland Ice Core Project and Dye 3 Greenland ice cores, J. Geophys. Res., 102(C12), 26 707-26723, 1997.

Delmonte, B., Petit, J.-R., Basile-Doelsch, I., Jagoutz, E., and Maggi, V.: Late Quaternary Interglacials in East Antarctica from ice core dust records, in: The Climate of Past Interglacials, edited by: Sirocko, F., Litt, T., and Claussen, M., Elsevier, Amsterdam, 2006.

Ditlevsen, P. D., Andersen, K. K., and Svensson, A.: The DOclimate events are probably noise induced:statistical investigation of the claimed 1470 years cycle, Clim. Past, 3, 129-134, 2007 ,

http://www.clim-past.net/3/129/2007/.

Eisen, O., Rack, W., Nixdorf, U., and Wilhelms, F.: Characteristics of accumulation in the vicinity of the EPICA deep-drilling site in Dronning Maud Land, Antarctica, Ann. Glaciol., 41, 41-46, 2005.

EPICA-community-members: Eight glacial cycles from an Antarctic ice core, Nature, 429, 623-628, doi:10.1038/nature02599, 2004.
EPICA-community-members: One-to-one coupling of glacial climate variability in Greenland and Antarctica, Nature, 444, 195198, doi:10.1038/nature05301, 2006.

Fox-Maule, C., Purucker, M. E., Olsen, N., and Mosegaard, K.: Heat flux anomalies in Antarctica revealed by satellite magnetic data, Science, 309, 464-467, doi:10.1126/science.1106888, 2005.

Hammer, C. U., Clausen, H. B., Dansgaard, W., Gundestrup, N., Johnsen, S. J., and Reeh, N.: Dating of Greenland ice cores by flow models, isotopes, volcanic debris, and continental dust, J. Glaciol., 20, 3-26, 1978.

MathWorks: Matlab, The Language of Technical Computing, The MathWorks, Inc., 2002.

Mulvaney, R., Röthlisberger, R., Wolff, E., Sommer, S., Schwander, J., Hutterli, M. A., and Jouzel, J.: The transition from the last glacial period in inland and near-coastal Antarctica, Geophys. Res. Lett., 27(17), 2673-2676, 2000.

NGRIP-project-members: High-resolution record of the Northern Hemisphere climate extending into the last interglacial period, Nature, 431, 147-151, 2004.

Oerter, H., Graf, W., Meyer, H., and Wilhelms, F.: The EPICA ice core from Dronning Maud Land: first results from stable-isotope measurements, Ann. Glaciol., 39, 307-312, 2004.

Oerter, H., Wilhelms, F., Jung-Rothenhäusler, F., Göktas, F., Miller, H., Graf, W., and Sommer, S.: Accumulation rates in Dronning Maud Land, Antarctica, as revealed by dielectric-profiling measurements of shallow firn cores, Ann. Glaciol., 30, 27-34, 2000.

Palmer, A. S., van Ommen, T. D., Curran, M. A. J., Morgan, V., Souney, J. M., and Mayewski, P.: High-rprecision dating of volcanic events (A.D. 1301-1995) using ice cores from Law Dome, Antarctica, J. Geophys. Res., 106(D22), 28 089-28 095, 2001.

Parrenin, F., Barnola, J.-M., Beer, J., Blunier, T., Castellano, E., Chappellaz, J., Dreyfus, G., Fischer, H., Fujita, S., Jouzel, J., Kawamura, K., Lemieux, B., Loulergue, L., Masson-Delmotte, V., Narcisi, B., Petit, J.-R., Raisbeck, G., Raynaud, D., Ruth, U., Schwander, J., Severi, M., Spahni, R., Steffensen, J. P., Svensson, A., Udisti, R., Waelbroeck, C., and Wolff, E.: The EDC3 agescale for the EPICA Dome $\mathrm{C}$ ice core, Clim. Past Discuss., 3 , 575-606, 2007, http://www.clim-past-discuss.net/3/575/2007/.

Rahmstorf, S.: Timing of abrupt climate change: A precise clock, Geophys. Res. Lett., 30, 1510-1513, doi:10.1029/2003GL017115, 2003.

Raisbeck, G., Yiou, F., Jouzel, J., and Stocker, T.: Direct NorthSouth synchronization of abrupt climate change record in ice cores using beryllium 10, Clim. Past Discuss., 3, 755-769, 2007, http://www.clim-past-discuss.net/3/755/2007/.

Rasmussen, S. O., Andersen, K. K., Svensson, A. M., Steffensen, J. P., Vinther, B. M., Clausen, H. B., Bigler, M., Röthlisberger, R., Siggaard-Andersen, M.-L., Johnsen, S. J., Fischer, H., GotoAzuma, K., Hansson, M., Larsen, L. B., and Ruth, U.: A new Greenland ice core chronology for the last glacial termination, J. Geophys. Res., 111, D06102, doi:10.1029/2005JD006079, 2006.

Röthlisberger, R., Bigler, M., Hutterli, A., Sommer, S., Stauffer, B., Junghans, H. G., and Wagenbach, D.: Technique for continuous high-resolution analysis of trace substances in firn and ice cores, Environ. Sci. Technol., 34, 338-342, 2000.

Rotschky, G., Eisen, O., Wilhelms, F., Nixdorf, U., and Oerter, H.: Spatial distribution of surface mass balance on Amundsenisen 
plateau, Antarctica, derived from ice-penetrating radar studies, Ann. Glaciol., 39, 265-270, 2004.

Schwander, J., Jouzel, J., Hammer, C. U., Petit, J.-R., Udisti, R., and Wolff, E.: A tentative chronlogy for the EPICA Dome Concordia ice core, Geophys. Res. Lett., 28(22), 4243-4246, 2001.

Severi, M., Castellano, E., Morganti, A., Udisti, R., Ruth, U., Fischer, H., Huybrechts, P., Wolff, E., Parrenin, F., Kaufmann, P., Lambert, F., and Steffensen, J. P.: EDML-EDC ice-core synchronisation for the last $52 \mathrm{kyr}$ by volcanic signatures matching, Clim. Past, 3, 367-374, 2007, http://www.clim-past.net/3/367/2007/.

Shapiro, N. M. and Ritzwoller, M.: Inferring surface heat flux distributions guided by a global seismic model: particular applications to Antarctica, Earth Planet. Sci. Lett., 223, 213-224, 2004.

Sommer, S., Appenzeller, C., Röthlisberger, R., Hutterli, M., Stauffer, B., Wagenbach, D., Oerter, H., Wilhelms, F., Miller, H., and Mulvaney, R.: Glacio-chemical study spanning the past 2 kyr on three ice cores from Dronning Maud Land, Antarctica - 1. Spatial and temporal variation of the accumulation rates, J. Geophys. Res., 105(D24), 29411-29421, 2000.

Svensson, A., Andersen, K. K., Bigler, M., Clausen, H. B., DahlJensen, D., Davies, S. M., Johnsen, S. J., Muscheler, R., Rasmussen, S. O., Röthlisberger, R., Steffensen, J. P., and Vinther, B. M.: The Greenland Ice Core Chronology 2005, 15-42 kyr. Part 2: Comparison to other records, Quaternary Sci. Rev., 25, 3258-3267, doi:10.1016/j.quascirev.2006.08.003, 2006.

Traufetter, F., Oerter, H., Fischer, H., Weller, R., and Miller, H.: Spatio-temporal variability in volcanic sulphate deposition over the past $2 \mathrm{kyr}$ in snow pits and firn cores from Amundsenisen, Antarctica, J. Glaciol., 50(168), 137-146, 2004.
Traversi, R., Becagli, S., Castellano, E., Migliori, A., Severi, M., and Udisti, R.: High-resolution fast ion chromatography (FIC) measurements of chloride, nitrate and sulphate along the EPICA Dome C ice core, Ann. Glaciol., 35, 291-298, 2002.

Udisti, R., Becagli, S., Castellano, E., Delmonte, B., Jouzel, J., Petit, J.-R., Schwander, J., Stenni, B., and Wolff, E.: Stratigraphic correlations between the European Project for Ice Coring in Antarctica (EPICA) Dome $\mathrm{C}$ and Vostok ice cores showing the relative variations of snow accumulation over the past $45 \mathrm{kyr}$, J. Geophys. Res., 109, D08101, doi:10.1029/2003JD004180, 2004.

Vinther, B. M., Clausen, H. B., Johnsen, S. J., Rasmussen, S. O., Andersen, K. K., Buchardt, S. L., Dahl-Jensen, D., Seierstad, I. K., Siggaard-Andersen, M. L., Steffensen, J. P., Svensson, A., Olsen, J., and Heinemeier, J.: A synchronized dating of three Greenland ice cores throughout the Holocene, J. Geophys. Res., 11, D13102, doi:10.1029/2005JD006921, 2006.

Wesche, C., Eisen, O., Oerter, H., Schulte, D., and Steinhage, D.: Surface topography and ice flow in the vicinity of EDML deepdrilling site, J. Glaciol., 53(182), in press, 2007.

Wolff, E., Basile, I., Petit, J.-R., and Schwander, J.: Comparison of Holocene electrical records from Dome C and Vostok, Antarctica, Ann. Glaciol., 29, 89-93, 1999.

Wolff, E., Cook, E., Barnes, P. R. F., and Mulvaney, R.: Signal variability in replicate ice cores, J. Glaciol., 51(174), 462-468, 2005. 